УДК 342.9

DOI https://doi.org/10.32837/pyuv.v2i3(28).364

\author{
О. А. Моргунов \\ кандидат юридичних наук, доцент, \\ завідувач кафедри спеціальної фізичної підготовки \\ Харківського національного університету внутрішніх справ
}

\title{
ПРАВОВЕ ЗАБЕЗПЕЧЕННЯ ПУБЛІЧНОГО АДМІНІСТРУВАННЯ СФЕР ФІЗИЧНОЇ КУЛЬТУРИ І СПОРТУ В УКРАЇНІ
}

Правове забезпечення сфер фізичної культури і спорту в Україні здійснюється на основі норм різних галузей права, серед яких традиційно виділяють господарське та цивільне. Однак не всі відносини сфер фізичної культури і спорту в Україні регулюються за допомогою методів вказаних галузей. Деякі відносини мають іншу правову природу.

Питання правового забезпечення сфер фізичної культури і спорту в Україні вивчалося низкою науковців. Серед них - В.Б. Авер'янов, В.А. Базенко, О.І. Безпалова, І.Д. Ваньчук, О.Є. Костюченко, С.В. Ліщук, С.В. Нікітенко та інші. Їх праці стали основою написання даної статі.

Проблема місця та значення норм адміністративного права у механізмі правового регулювання відносин, які виникають у сферах фізичної культури та спорту в Україні, може бути висвітлена та вирішена на основі аналізу галузевої належності норм, що складають правове забезпечення публічного адміністрування сфер фізичної культури i спорту в Україні.

Метою статті є встановлення місця і ролі адміністративно-правового забезпечення сфер фізичної культури і спорту в Україні через визначення галузевої належності норм, які становлять основу правового забезпечення публічного адміністрування вказаних сфер, а також з'ясування значення таких норм в механізмі правового регулювання сфер фізичної культури і спорту в Україні.

Для досягнення мети даної статті необхідно 3'ясувати зміст категорії правового забезпечення. Щодо вирішення цього питання існують різні позиції науковців. Наприклад, О.Є Костюченко визначає правове забезпечення як безперервну діяльність суб'єктів права в межах їх компетенції зі створення правових умов усіма правовими засобами щодо закріплення, реалізації, гарантування, охорони та захисту прав і свобод осіб та їх груп [1, с. 15]. Правове забезпечення, як вважає І.Д. Ваньчук, має розглядатися як специфічна система нормативного впливу на суспільно значущі, свідомо-вольові, повторні та стійкі суспільні відносини з метою їх упорядкування, що реалізується через визначення базових складників зазначених відносин з використанням спеціальних юридичних засобів [2, с. 10]. Досліджуючи механізми правового регулювання органів поліції,
O.I. Безпалова виокремлює дві складові частини - статичну та динамічну. Статичний складник включає в себе правові норми, які регламентують специфіку управління. Інші ж елементи правового механізму управління (інституційна складова частина, принципи, форми й методи, правовідносини та ресурсна складова частина) виступають динамічним складником. Без належним чином налагодженого статичного складника ефективність усього механізму буде мінімальною. Статичний показник вчена пов'язує з правовим забезпеченням, зміст якого полягає у формуванні необхідної правової бази, яка б створювала необхідні умови для функціонування системи, всебічно регламентувала б особливості розподілу функцій між окремими їі елементами, а також специфіку виконання ними покладених на них обов'язків [3]. Саме в наведеному значенні ми будемо аналізувати правове забезпечення публічного адміністрування сфер фізичної культури і спорту в даній статті.

Норми, які є підставою здійснення публічного адміністрування сфер фізичної культури і спорту, були включені до Конституції України [4]. Відповідно до Основного Закону громадяни України мають право займатися фізичною культурою i спортом незалежно від походження, соціального і майнового стану, расової і національної належності, статі, освіти, віросповідання, роду і характеру занять, місця проживання та інших обставин. Україна гарантує надання в порядку, передбаченому Кабінетом Міністрів України, безкоштовних і пільгових фізкультурно-оздоровчих послуг дітям, у тому числі й дітям-сиротам та дітям, що залишилися без піклування батьків, дітям, що постраждали внаслідок Чорнобильської катастрофи, дітям-інвалідам тощо. Пріоритети державної політики втілились у відповідних законодавчих та нормативно-правових актах - законах, указах Президента, постановах Верховної Ради України та Кабінету Міністрів України, наказах та нормативно-методичних документах [5, с. 95-96]. При цьому всі акти, які у сукупності становлять підстави правового забезпечення публічного адміністрування сфер фізичної культури і спорту, належать до джерел різних галузей права.

C.В. Ліщук стверджує: «Традиційними актами, які регулюють фізкультурно-оздоровчі і спор- 
тивні відносини, є Цивільний і Господарський кодекси України" [6]. С.В. Нікітенко звертає увагу на виокремлення декількох підходів щодо питання регулювання відносин у сфері професійного спорту за участю спортсменів-професіоналів. Перший з них полягає в тому, що відносини, які виникають у спортсмена-професіонала з фізкультурно-спортивною організацією, регулюються законодавством про працю, норми якого доповнюються нормами вітчизняного і міжнародного права. Другий підхід грунтується на тому, що вказані відносини можуть регулюватися як нормами законодавства про працю, так і нормами чинного цивільного законодавства [5, с. 97-98]. Як бачимо, правове забезпечення відносин у сферах фізичної культури і спорту охоплює норми цивільного, господарського, трудового права.

Однак у досліджуваних сферах складаються i відносини, які будуються на засадах влади та підпорядкування, передбачають застосування примусу, імперативність методу регулювання та інші ознаки, які не притаманні предметам і методам перерахованих вище галузей права. Такі відносини, наприклад, виникають у зв'язку з порушенням прав спортсменів, при визначенні та впровадженні державної політики у сферах фізичної культури та спорту, при наданні чи зміні дитячо-юнацьким спортивним школам певної категоpiї тощо. Відповідні відносини є адміністративними за своєю правовою природою, тому їх правове забезпечення здійснюється на основі норм адміністративного права.

До числа таких відносин входять і ті, що виникають за участю суб'єктів публічного адміністрування. Однак значення адміністративного права в механізмі правового регулювання відносин у сферах фізичної культури та спорту не обмежується правовим забезпеченням публічного адміністрування. Наприклад, у взаємодії професійних спортсменів зі спортивними клубами та федераціями часто нехтуються права професійних спортсменів, оскільки, як правило, саме вони є слабшою ланкою в цих взаємовідносинах, тому вони потребують правового захисту [5, с. 99]. Захист професійних спортсменів забезпечується нормами адміністративного права як щодо статусу суб'єктів захисту, форм, методів тощо, так і в аспекті визначення підстав та порядку захисту. Кодекс України про адміністративну відповідальність визначає ті дії чи бездіяльність суб'єктів чи об'єктів управлінської системи, які становлять склади адміністративних правопорушень у сферах фізичної культури та спорту, а також санкції за вчинення адміністративних правопорушень, підстави та порядок притягнення до юридичної відповідальності.

Повернемось до виділення норм, які є основою публічного адміністрування у сферах фізичної культури і спорту. Зокрема, це норми, які визна- чають статус, межі та форми участі суб'єктів публічного адміністрування у формуванні державної політики, її реалізації та при виконанні інших функцій у сферах фізичної культури та спорту, а також методи управління, доступні даним суб' єктам.

Це норми, якими визначаються пріоритети державної політики в галузях фізичної культури і спорту. Їх, наприклад, включає Концепція Державної цільової соціальної програми розвитку фізичної культури і спорту на період до 2020 року [7]. Указом Президента України від 9 лютого 2016 року № 42/2016 затверджена Національна стратегія з оздоровчої рухової активності в Україні на період до 2025 року «Рухова активність здоровий спосіб життя - здорова нація» [8, с. 172].

Загалом державні програми та стратегії розвитку фізичної культури і спорту в Україні, спрямовані на практичну реалізацію Закону України «Про фізичну культуру і спорт», розкривають основні напрями державної політики в галузі фізичної культури і спорту, визначають їх роль у житті суспільства, показують тенденції розвитку фізкультурно-спортивного руху та окреслюють практичні заходи щодо впровадження фізичної культури в побут громадян, а також основні засади організаційного, матеріально-технічного, кадрового, інформаційного забезпечення на певних етапах суспільного розвитку. На основі Державної програми розвитку фізичної культури і спорту Кабінет Міністрів України передбачає відповідний розділ у програмах економічного і соціального розвитку України [6]. С.В. Нікітенко визначає основні переваги вирішення проблем публічного адміністрування сфер фізичної культури та спорту за допомогою програмно-цільового методу. По-перше, комплексний підхід до вирішення проблеми - формування мети, завдань і основних напрямів реалізації програми - дозволяе врахувати всі аспекти розвитку фізичної культури і спорту в Україні, визначити пріоритетність тих чи інших заходів (видів спорту) в ході реалізації програми. По-друге, в межах програми проводиться чіткий розподіл повноважень між органами виконавчої влади на центральному, регіональному і муніципальному рівнях, передбачається участь у програмі громадських організацій, комерційних структур тощо. По-третє, ефективне планування i моніторинг результатів реалізації програми можливі завдяки розробці показників ефективності та цільових індикаторів, які дозволяють щорічно оцінювати результати [5, с. 98-99].

Адміністративними нормами врегульовано контроль та нагляд у сферах фізичної культури та спорту не тільки в аспекті статусу суб'єктів, про який ми зазначили вище, але і стосовно тих вимог, які беруться за основу під час порівняння норм, якими встановлюються певні вимоги до об'єктів сфер фізичної культури та спорту, їх діяльності. 
Наприклад, Кабінет Міністрів України 15 січня 1996 р. затвердив Положення «Про державні тести і нормативи оцінки фізичної підготовленості населення України». Цей документ є основою нормативних вимог до фізичної підготовленості громадян нашої країни як критерію фізичного здоров'я, дає змогу визначити рівень фізичної підготовленості всіх груп і категорій населення, здійснювати державний контроль за ефективністю фізичного виховання [5, с. 98]. Аналізуючи положення Закону «Про ліцензування певних видів господарської діяльності», С.В. Ліщук підкреслив, що фізкультурно-оздоровча і спортивна діяльність (певні її види) розглядаються як види господарської діяльності і належать до обмежувальних видів господарської діяльності, для здійснення яких потрібне отримання спеціального дозволу - ліцензії. Даний Закон визначає загальне поняття ліцензії, ліцензійних умов, називає органи, які здійснюють ліцензування, документи, необхідні для отримання ліцензії, і регламентує весь процес видачі ліцензій [6].

Провідне місце у правовому забезпеченні сфер фізичної культури і спорту належить нормам адміністративного права, які становлять основу публічного адміністрування вказаних сфер, визначаючи статус суб'єктів публічного адміністрування, принципи, підстави, форми і методи їх службової діяльності, пріоритети та шляхи формування державної політики в галузях фізичної культури і спорту, засоби та процедури її впровадження, регулюють контроль та нагляд у вказаних сферах.

\section{Jimepamypa}

1. Костюченко О.Є. Визначення поняття «правове забезпечення». Науковий вісник Національного університету державної податкової служби Украйни. 2015. № 1 (68). С. 11-16.

2. Ваньчук І.Д. Поняття й сутнісні ознаки правового регулювання суспільних відносин: сучасний погляд. Науковий вісник Ужгородського національного університету. Серія «Право». 2015. Вип. 32 (1). С. 7-10.

3. Безпалова О.І. Правове забезпечення управління органами поліції України. Підприємниитво, господарство і право. 2017. № 9. С. 111-115.

4. Конституція України : Закон України від 28.06.1996 № 254к/96-ВР. Офіиійний вісник України. 2010. № 72/1. Спеціальний випуск. С. 15. Ст. 2598.

5. Нікітенко С.В. Особливості нормативно-правового регулювання фізичного виховання і спорту в Україні. Державне управління та місиеве самоврядування. 2016. Вип. 1. С. $95-100$.

6. Ліщук С.В. Система державного регулювання у сфері фізичної культури та спорту в Україні. Державне управління: удосконалення та розвиток. 2014. № 12. URL: http://www.dy.nayka.com.ua/?op=1\&z=794 (дата звернення: 25.10.2018).
7. Про схвалення Концепції Державної цільової соціальної програми розвитку фізичної культури і спорту на період до 2020 року : Розпорядження Кабінету Міністрів України від 09.12.2015 р. № 1320-р. Oфiuiйний вісник України. 2015. № 102. С. 163. Ст. 3529. Код акта $79963 / 2015$.

8. Базенко В.А Механізм підтримки розвитку фiзичної культури та спорту в умовах децентралізації. Молодий вчений. 2017. № 1 (41). С. 172-178.

\section{Анотація}

Моргунов О. А. Правове забезпечення публічного адміністрування сфер фізичної культури і спорту в Україні. - Стаття.

Метою даної статті є встановлення місця і ролі адміністративно-правового забезпечення сфер фізичної культури і спорту в Україні через визначення галузевої належності норм, які складають основу правового забезпечення публічного адміністрування вказаних сфер, а також з'ясування значення таких норм в механізмі правового регулювання сфер фізичної культури і спорту в Україні. У статті встановлені місце і роль адміністративно-правового забезпечення сфер фізичної культури і спорту в Україні через визначення галузевої належності норм, які складають основу правового забезпечення публічного адміністрування вказаних сфер. Визначено, що захист професійних спортсменів забезпечується нормами адміністративного права як щодо статусу суб'єктів захисту, його форм, методів тощо, так і в аспекті визначення підстав та порядку захисту. Кодекс України про адміністративну відповідальність визначає ті дії чи бездіяльність суб'єктів чи об'єктів управлінської системи, які становлять склади адміністративних правопорушень у сферах фізичної культури та спорту, а також санкції за вчинення адміністративних правопорушень, підстави та порядок притягнення до юридичної відповідальності. 3'ясовано, що у сферах фізичної культури і спорту складаються відносини, які будуються на засадах влади та підпорядкування, передбачають застосування примусу, імперативність методу регулювання та інші ознаки, які не притаманні предметам і методам перерахованих вище галузей права. Такі відносини, наприклад, виникають у зв'язку з порушенням прав спортсменів, при визначенні та впровадженні державної політики у сферах фізичної культури та спорту, при наданні чи зміні дитячо-юнацьким спортивним школам певної категорії тощо. Зроблено висновок, що провідне місце у правовому забезпеченні сфер фізичної культури і спорту належить нормам адміністративного права, які складають основу публічного адміністрування вказаних сфер, визначаючи статус суб'єктів публічного адміністрування, принципи, підстави, форми і методи їх службової діяльності, пріоритети та шляхи формування державної політики в галузях фізичної культури і спорту, засоби та процедури її впровадження, регулюють контроль та нагляд у вказаних сферах.

Ключові слова: правове забезпечення, правове регулювання, публічне адміністрування, публічне управління, управління спортом, управління у сфері фізичної культури. 


\section{Summary}

Morhunov O. A. Legal support of public administration in the area of physical culture and sports in Ukraine. - Article.

The purpose of this article is to establish the place and role of administrative and legal support of physical culture and sports in Ukraine by determining the sectoral affiliation of the norms that form the basis of legal support for the public administration of these areas, and the importance of such norms in the mechanism of legal regulation of physical culture and sports in Ukraine. In the article is established the place and role of administrative law for regulation on the sphere of physical culture and sports in Ukraine through the definition of the sectoral affiliation of the norms that form the basis of the legal support of public administration of these areas. It is determined that the protection of professional athletes is ensured by the rules of administrative law, both in terms of the status of the subjects of defense, its forms, methods, etc., as well as in terms of defining the grounds and the order of protection. The Code of Administrative Liability defines the actions or omissions of the subjects or objects of the administrative system that constitute the administrative offenses in the fields of physical culture and sports, as well as sanctions for committing administrative offenses, grounds and procedure for bringing to this type of legal responsibility. It has been found out that in the fields of physical culture and sports, relations are formed, which are based on the principles of power and subordination, imply the use of coercion, imperativeness of the method of regulation and niches, signs that are not inherent in the subjects and methods of the above fields of law. It is emphasized that in the spheres of physical culture and sports relations are formed, which are based on the principles of power and subordination, imply the use of coercion, imperativeness of the method of regulation and niches, signs that are not inherent in the subjects and methods of the above mentioned branches of law. Such relationships, for example, arise from the violation of the rights of athletes, when defining and implementing state policies in the fields of physical culture and sports, when granting or changing children's and youth sports schools of a certain category, etc. It is concluded that the leading place in the legal support of the physical education and sports spheres belongs to the rules of administrative law, which form the basis of public administration of these spheres, determining the status of public administration entities, principles, grounds, forms and methods of their official activity, priorities and ways of formation state policies in the fields of physical culture and sports, the means and procedures for its implementation, regulate control and supervision in these areas.

Key words: legal support, legal regulation, public administration, public management, management of sports, management in the field of physical culture. 